\title{
Mobile Game-Based Learning (mGBL): Application Development and Heuristics Evaluation Strategy
}

\author{
*SYAMSUL BAHRIN ZAIBON \\ NORSHUHADA SHIRATUDDIN \\ Universiti Utara Malaysia \\ *(syamsulbahrin@uum.edu.my)
}

\begin{abstract}
Purpose - This article presents an approach to developing a mobile game-based learning (mGBL) application by adapting unified characteristics of learning theories and approaches. In addition, the study also identified the strategy to evaluate mGBL.

Method - The study utilized the design research approach in information systems. The research methodology can be divided into five phases; (i) awareness of problem (ii) suggestion (iii) development (iv) evaluation and (v) conclusion.

Findings - Unified characteristics of mGBL were identified. In adapting the characteristics, the mGBL application was developed based on the concept of values in 1Malaysia. To evaluate the mGBL, a heuristics evaluation strategy is proposed. The strategy consists of four components: Game Usability, Mobility, Game Play, and Learning Content. Each of the components represents the issues to be considered and evaluated for a mGBL.

Value - The study provides intensive review of $\mathrm{mGBL}$ characteristics that can be useful and may be of interest to game developers. In addition the heuristics evaluation strategy is developed for evaluating the effectiveness of mGBL application.
\end{abstract}

Keywords: mGBL, mobile game-based learning, development, characteristics, heuristics evaluation

\section{INTRODUCTION}

In recent years, information and communication technologies (ICT) have been treated as notable solutions in social, economics, culture 
and education aspects. The field of education particularly has been eminently impacted by these ICT. As evidence, there is increasing interest in the use of ICT and educational technologies to promote learning formally or informally. These technologies are not limited to computers and software, but all tools are utilised for teaching and learning such as compact disc (CD), video compact disc (VCD), cameras, mobile phone, personal digital assistance (PDA), global positioning system (GPS) devices, computer-based probes, and electronic tools which have yet to be realised. With the capability of such technologies there are various types of educational applications readily obtainable in the market such as courseware, tutorial, simulation, electronic book; all of which are available either on CD or from the Internet.

Although there are many types of educational applications, the main purpose of the designed technologies is to facilitate effective and efficient learning. Learning via these applications can be categorised into a number of terms such as web-based or online learning, Computer-Based Learning (CBL), Computer-Based Training (CBT), and most recently mobile learning (m-learning); all are sub domain of electronic learning (e-learning).

Mobile-learning (m-learning) can be described as a learning technique that takes place across locations or gets the advantage of learning opportunities offered by mobile technologies such as mobile phones, smart phones, PDAs, and handheld devices. Basically, m-learning combines practices, strategies, tools, applications, and resources with proven advances in technology to support anywhere and anytime learning (Wagner, 2005). The most prominent promises by mobile technologies are where students can learn with no location restriction to places; in classroom or outside, with teachers' guidance or without, during class period or anytime. Many research findings showed the potential and effective use of mobile technologies for learning purposes as stated for instance by Naismith et al. (2006); and Pachler (2007). Moreover, there are varieties of m-learning systems (Short Message Service (SMS) text message, Mobile Games, Mobile Applications) that have been successfully implemented (Naismith, Lonscale, Vovoula, and Sharples, (2006), Pachler, 2007), as listed in Table 1.

Using SMS for m-learning is rather simple, yet effective as a complementary media. With SMS technology, short text messages and educational information can be written and sent quickly with any mobile phone. This offers enormous learning opportunities. Also, mobile games used in the m-learning environment offer a rich and 
interactive learning experience where game play is used to enhance learning by promoting learning through motivation. Through mobile games, the activity of playing will engage and stimulate students, as well as promote teamwork, skill building, and interactive problem (Sugar, \& Sugar, 2002). Mobile applications for m-learning are smaller versions of desktop learning systems, that are specially developed for mobile devices. The mobile applications are rather more complicated than SMS system and usually have more learning contents which are managed by database systems.

Table 1

Example of M-learning Systems

\begin{tabular}{|c|c|c|}
\hline $\begin{array}{l}\text { Application } \\
\text { Types }\end{array}$ & Project Names & Authors \\
\hline $\begin{array}{l}\text { SMS text } \\
\text { message }\end{array}$ & $\begin{array}{l}\text { - BBC Bitesize Programme } \\
\text { - M-learning Language System } \\
\text { - Learning System (Blackboard) }\end{array}$ & $\begin{array}{l}\text { - BBC Bitesize (2008) } \\
\text { - Thornton and Houser (2004) } \\
\text { - Vassell, Amin and Patel (2006) }\end{array}$ \\
\hline $\begin{array}{l}\text { Mobile } \\
\text { Game }\end{array}$ & $\begin{array}{l}\text { - Mathematic Video Game-Skills } \\
\text { Area } \\
\text { - Virus } \\
\text { - MIT Game-To-Teach }\end{array}$ & $\begin{array}{l}\text { - Mitchell, Inchingolo, Vatta, Gricar, } \\
\text { Cisic, Petrovic, Kittl, and Peyha } \\
\text { (2006) } \\
\text { - Lee, Luchini, Michael, Norris, and } \\
\text { Soloway (2004) } \\
\text { - Collella (2000) } \\
\text { - Klopfer and Squire (2002) }\end{array}$ \\
\hline $\begin{array}{l}\text { Mobile } \\
\text { Application }\end{array}$ & $\begin{array}{l}\text { - Classroom Response System- } \\
\text { Educue } \\
\text { - Ambient Wood }\end{array}$ & $\begin{array}{l}\text { - Dufresne, Gerace, Leonard, Mestre, } \\
\text { and Wenk (1996) } \\
\text { - Rogers, Price, Harris, Phelps, } \\
\text { Underwood, Wilde, and Smith } \\
\text { (2002) } \\
\text { - Chen, Kao, Yu, and Sheu (2004) } \\
\text { - Proctor and Burton (2003) }\end{array}$ \\
\hline
\end{tabular}

One of the possible novelties regarding the m-learning methods, which is discussed in this study, is the use of games. As a matter of fact, Rieber (1996) argued that as human beings, by nature, we begin to learn through games and play from early childhood. Consequently, up untill now, games are replaced by formal learning at kindergarten schools. In our modern day, with the new technological advancement in learning, traditional games of old times have been replaced by digital games (computer, console, and mobile games). Hence, nowadays digital games are part of contemporary learning. Furthermore, the method of learning 
through mobile devices is becoming popular and this is shown by the growing number of available m-learning applications. Also, many researchers have shown the potential use of game in the learning environment.

The next section details the methodology followed in this study. The research motivation, objectives, and questions, which are also described as part of the outcomes of the phases in the methodology.

\section{RESEARCH METHODOLOGY}

A prominent design science research methodology (Vaishnavi \& Kuechler, 2007) is adopted for accomplishing the research objectives. Their research methodology can be divided into five phases, namely (i) awareness of problem, (ii) suggestion, (iii) development, (iv) evaluation, and (v) conclusion. Figure 1 illustrates the activities that were conducted in this study.

In the first phase, the problem of this research was defined through literature study and content analysis. The problem statement was established based on these activities and from the aspects that motivate the study. These problems to the construction of the research objectives and questions.

In phase two of this research, the analysis of learning theories and approaches were used to compare and document the mGBL characteristics. In addition, a further study on the flow and cycle of the mGBL development was also conducted to determine an appropriate solution. Next, the mGBL application was developed based on the needs of Malaysian local content, where the 1Malaysia concept was adopted since it is the current national agenda. The development of mGBL prototype followed the characteristics, which were proposed in the previous phase.

Then, the mGBL application was evaluated using the proposed heuristics evaluation strategy. In the final phase, claims and evidences will be justified through analysis of findings. All of these phases and activities are further described in the next sections.

\section{RESEARCH MOTIVATION AND OBJECTIVE}

International Telecommunication Union (ITU) Telecommunication/ ICT Indicators Report (ITU, 2008) found evidence that ICT, broadband and mobile phone uptake foster growth and development 
in the Asia Pacific region. In Malaysia, mobile phone subscriptions have reached 25 million in the second quarter of 2008. According to the research conducted by the Malaysian Communications and Multimedia Commission (MCMC), the number of mobile wireless phone users has also exceeded those of the fixed lines (MCMC, 2009).

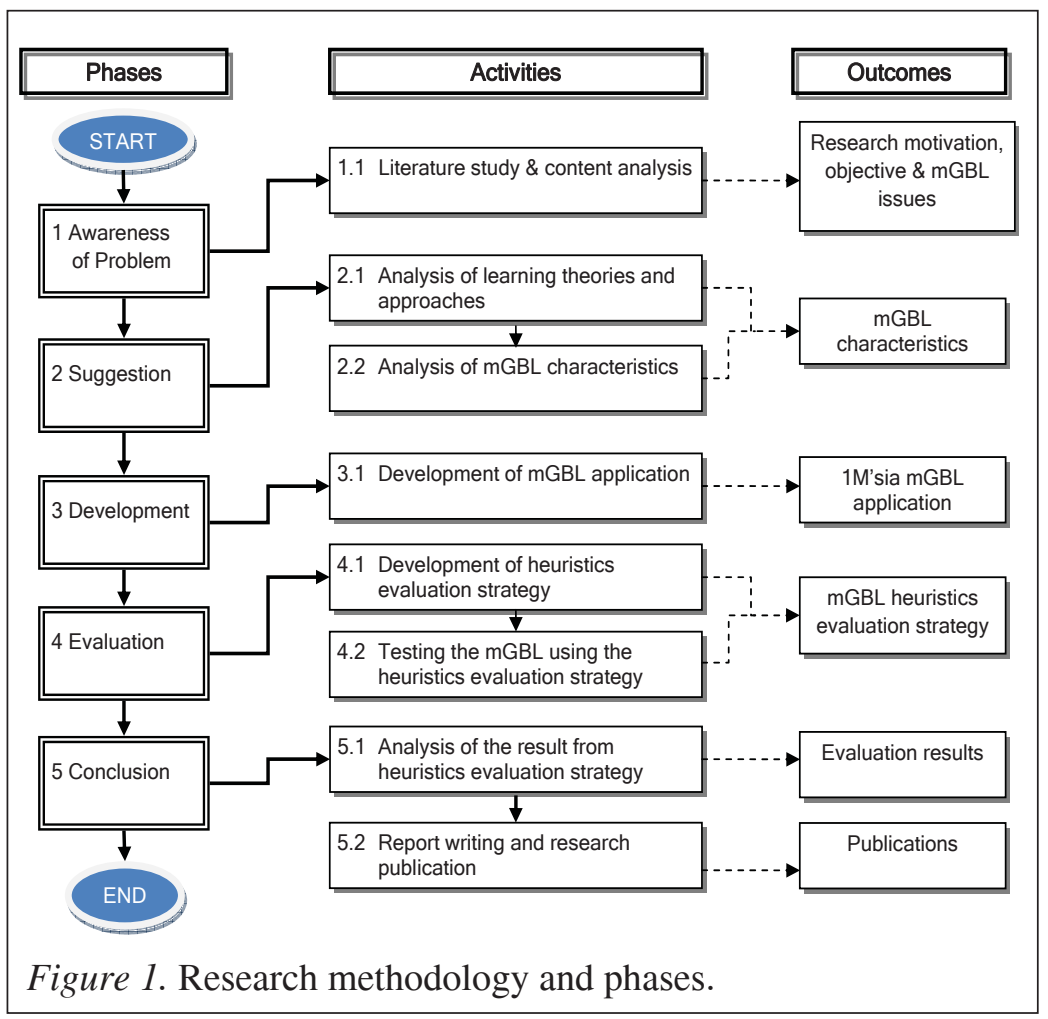

As of the first quarter of 2005, there were 15 million mobile phone subscriptions on all mobile networks operating in Malaysia. In the first quarter of 2006, the number had increased to 20.5 million, a $5.3 \%$ growth rate and $77.7 \%$ penetration rate nationwide. This number has continually increased up to 25 million and shows that there has been a dramatic increase in the usage of mobile phones among Malaysians.

The percentage of the penetration rate in Malaysia rose from only $9.7 \%$ in 1998 to $90.6 \%$ in 2008. Similarly, mobile growth rates have been high across almost all regions and the number of subscribers has grown between 20 to $30 \%$ globally since 2000 (ITU, 2008). Some of the reasons for this trend are the decreasing prices of mobile phones and variety of services provided by the operators. 
Based on such empirical evidence, there is a huge potential of usage in the mobile learning environment. Hence, in tapping the thriving mobile business, a study on mobile content development, specifically local content, is urgently required. The Malaysian government has come up with a strategy called MyICMS 886, which dictates a number of strategies for the growth of local content and these are promoting awareness, building competencies in higher education and forming strategic alliances. The goals are to encourage local creativity, address new content demands and also export content. In achieving these goals, the Malaysian government together with a number of key industry players have provided many funding incentives specifically for local content production. This is expected to provide adequate local contents that reflect Malaysian culture and values. It is also expected the contents should be sold as additional services by mobile operators to broaden phone usage (Pelkonen, 2004).

In the Malaysian local scene, Roslan (2007) reported that local content development is highly indeed for education, entertainment, and games. Moreover, IGDA (2005) also indicated that over the last several years there have been two significant changes in the landscape for mobile gaming. Firstly, the potential size of the market for mobile gaming has grown considerably since 2000, and secondly the quantity of mobile games available nowadays. Therefore, in an effort for ensuring this potential mode of enriching the learning environments is seized, a design study of mobile game has been undertaken.

In order to take advantage of the positive aspects of games for learning, the design and development of mGBL ought to be studied like any form of instructional material, which must be carefully and intelligently designed. For that reason, there is a clear need for design theories which not only clearly define how to design an effective educational game, but also focus on providing the necessary support for the implementation to improve its learning effectiveness.

Based on all the above-mentioned motivations, the objective of this study was to develop structurally the mGBL, which would contribute to the current demand in the local content production. A number of research questions were constructed in accomplishing the objective and these are:

- What are the characteristics of a mGBL?

- What are the current practice in mGBL development process?

- How should mGBL be successfully developed?

- What would be the dimensions for mGBL evaluation?

- How should the evaluation process of mGBL be? 


\section{MOBILE GAME-BASED LEARNING}

Games are known as good platforms to motivate people to play, interact, communicate, as well as learn. Game and learning can be successfully developed and implemented in the learning environment by combining both game design and instructional design approaches. This section discusses these issues in the mobile environment.

Although there are many application types in m-learning, this research focused on the mobile game as the focus of study. Mobile game for learning or mobile game-based learning (mGBL) is a game specifically utilised for learning but is played on portable devices. Similar to game-based learning (GBL), the main aim of mGBL is to use game play to enhance motivation in order to learn, to engage in knowledge acquisition, and to enhance effectiveness of learning content transfer or other specific learning outcome (Pivec, 2005; Goodman, Bradley, Paras, Williamson, \& Bizzochi, 2006).

The mGBL application is a GBL that utilises mobile technologies such as mobile phone, PDA and handheld devices for its playing platform. Mohamudally (2006) described that the issues concerning of $\mathrm{mGBL}$ are mobility and restrictions on mobile technologies. He further stated that the mGBL concepts are grounded in pedagogical theory and adjusted to the technical capabilities of current standard mobile phones.

These mGBL applications are developed for a broad variety of learning contexts such as role play and multiplayer games (Sanneblad \& Holmquist, 2003; Lonsdale, Baber, Sharples, 2004; McAlister \& Xie, 2005; Mohamudally, 2006), or GBL of C++ (Siti Hafizah \& Fung, 2007). Some mGBL applications focus on collaboration (Sanneblad \& Holmquist, 2003; Sanchez, Salinas, \& Saenz, 2006); and on the contrary, others are mainly played individually (Krenn, Bohme, \& Mitchell, 2008). Another example is from Mitchel, Inchingolo, Vatta, Gricar, Cisis, Petrovic, Kitti, \& Peyha (2006) who proposed the three year pan-European funded project, which prototyped mGBL in three sectors: i) e-health, ii) e-commerce, and iii) career guidance. The project was based on research findings that were published by Mitchell (2003), and Mitchell and Savill-Smith (2004). Their findings showed that mGBL has considerable potential for promoting and encouraging learning.

Therefore the characteristics of mGBL need to be explored and these are explained in the next section.

\section{Characteristics of $m G B L$}

The interesting feature about a mobile game is its wide reach due to mobile phone being the most commonly carried personal device. 
In contrast to console games that target youngsters and teenagers, mobile games are more accessible to everyone (Yuan, 2003). Studies have shown that mobile games also give a substantial paradigm change from console games due to the hugely different target user, lifestyle, and distribution strategies. As described by Yuan (2003), Trifonova (2003), and Mitchel (2006), mGBL characteristics can be summarised as follows:

i) Easy to learn: Mobile games cannot have steep learning curves since they are targeted for all type of users because they will not spend hours reading the game operation manual. Therefore, it is important to keep the game simple.

ii) Rich social interactions: Mobile games quickly become uninteresting when the player discovers the game pattern or has exhausted all the play activities. To solve this, the mobile game (especially subscription-based) can be incorporated with other players to increase the intelligence and randomness of game play.

iii) Interruptible: Mobile phone users often have little free time available between tasks (e.g. while waiting for a bus or a taxi). The same mobile device is also used for games, messaging, picture taking, and data access. Therefore, a worthy mobile game should allow users to switch smoothly between tasks and provide entertainment value for short time periods.

iv) Subscription based: Mobile game revenue depends on their large distribution. It is indeed expensive to design and develop each game from scratch. Thus it is significant to offer different titles from the same game engine along similar basic storylines. Subscription-based mobile games are the best way to generate sustained revenue.

v) Take advantage of mobile innovations: Good mobile games should take advantage of the enhanced mobile technologies and services such as Global Positioning System (GPS) extensions and Short Message Service (SMS)/Multimedia Message Service (MMS) messaging.

vi) Nonexplicit content: Since all range of ages and gender play mobile games and often in public or work settings, explicit violent or sexual content must be avoided.

vii) Short, not more that 5-10 minute modules. The players should be able to use their short waiting time for learning, like doing quizzes, reading small pieces of data, or using forums or chat. 
viii) Simple, funny, and added value functionality. The limited properties of mobile devices make it complicated to use complex and multimedia content. Players should be able to use the learning game without having to read a user manual.

ix) Area/domain specific content, delivered just in time or place. The mobility capability should be able to guide and support students and teachers in new learning situations whenever and wherever it is necessary. The dependency of the content can be relative to location context (i.e. based on learner location), temporal context (i.e. based on time), behavioural context (i.e. based on learner behaviour), and interest specific context (i.e. based on learner's preferences).

x) Self-explaining. Learning applications should be selfexplaining and support a playful way of learning.

xi) Small units of learning contents. The learning contents should be split into small units which require only a reduced span of attention so that game play and learning can take place during pauses.

xii) Available any time. The learning contents should be available any time, and the games should be integrated in the situational and local context of the learner.

The principles and unified characteristics of mGBL presented in this section provide a conceptual overview of what could become a good practice for the development of mGBL. The next section discusses another key mGBL element that needs to be an integral part of the mGBL development process, which is learning theories.

\section{OVERVIEW OF LEARNING THEORIES}

A learning theory is an attempt to know how people learn, and in helping us understand the process of learning. When tools are associated with learning, it is not feasible to ignore the learning theories. Therefore, the dominant learning theories that shape the learning landscape through mGBL will be discussed in this section.

There are various different theories of learning. These available theories are useful in considering their application to the learning environment. Some theories focus on ways to describe and control observations, behaviours, and events of learning. Others attempt to describe the framework of learning such as the nature of attention, the way memories are formed, and the way learners process and give meaning to knowledge. Learning theories are 
likely to fall into several main paradigms, including behaviourism, cognitivism, and constructivism; which are briefly described in this section.

\section{Behaviourism}

Kang (2004) described that behaviourism theory started in the early 20th century and the proponents are Bandura, Watson, Skinner, and Pavlov. Behaviourism is known as a paradigm that assumes the learner is passive and responding to environmental stimulus (Kettanurak, Ramamurthy, \& Haseman, 2001). The learner starts from knowing nothing and then his behaviour is shaped through reinforcement (positive or negative). Both positive and negative reinforcement increase the probability that the antecedent behaviour will happen again. On the contrary, punishment decreases the likelihood that the antecedent behaviour will happen again. Hence, this theory describes that learning happens when a correct response is demonstrated. The strength of this theory is when the learners are focused on a clear goal, thus they can respond automatically to the cues of that goal. This will accomplish the learning objectives. On the other hand, the weakness is when the learners may find themselves in a situation where the correct response does not occur; the learners cannot give response. This theory has been criticised because it can be applied in a situation where the learning environment is at the lower level of skill or knowledge. Conversely, this theory can be applied successfully when the learning environment supports good and immediate responses (Kettanurak, Ramamurthy \& Haseman, 2001).

\section{Cognitivism}

The revolution of cognitivism has replaced behaviourism in the 1960s as the leading paradigm (Kang, 2004). The focus of cognitivism is on the inner mental activities of the human mind because it is precious and necessary to understand how people actually learn (Kettanurak et al., 2001). Mental activities such as thinking, knowing, memorising, and problem-solving are focused in this theory which create the knowledge. The knowledge can be seen as schema or symbolic mental constructions. According to Kang (2004), this theory has been widely used and impacted the learning environment. Kang further described that the cognitive process is the main focus for learning resources. As to differentiate with 
behaviourism, learning is a change of knowledge state. The strength of this theory is that learners are trained to do a task in similar way to allow consistency. This will make the learners solve a problem using their own possible solutions. However, the weakness is when the learners are able to accomplish a task, but not through the best suited way to the learners.

\section{Constructivism}

In constructivism, learning is seen as an active process of constructing knowledge rather than acquiring it (Kettanurak et al., 2001). Knowledge is created based on learner experiences and interactions. They actively construct or create their own understanding by assembling knowledge from diverse sources appropriate to the problem at hand. New information is gathered by linking to prior knowledge and experiences. Constructive theory is the main contributor toward the successful learning process in 1990s (Kang, 2004). This theory focuses on the learners rather than instructors. An individual learner is unique with his own capability of learning. He is encouraged to show his skills and potential that are useful for him in the learning environment. Vygotsky's social development theory is one of the foundations for constructivism which stresses on keys of human development, such as interpersonal (social), cultural-historical, and individual factors (Kettanurak et al., 2001). The advantage of this theory is when the learner is able to understand various realities; he is better able to deal with real life situations. If a learner can solve problems, he is better at applying his existing knowledge to other circumstances (Schuman, 1996). On the other hand, in a situation where agreement is essential, different thinking and action of different people may cause problems, especially when the situation needs only the right and exact decision (Schuman, 1996).

\section{Implications of Learning Theories to mGBL Characteristics}

Developing instructional tools requires specific elements which include learning theories and an instructional design model. The designers are required to embed learning theories into the design and adopt an instructional design model during the development of instructional tools. Table 2 and 3 show the summary of these theories that can be adopted for developing mGBL. 


\section{Table 2}

$m G B L$ Advantages from the Learning Theories (Egenfeldt-Nielsen, 2006)

\begin{tabular}{ll}
\hline Learning Theories & Advantages \\
\hline Behaviourism & - $\begin{array}{l}\text { Behaviourism provides the concept of repetition and } \\
\text { reward. } \\
\text { - }\end{array}$ \\
& The player practices in a game through repetition while \\
& receiving rewards after each proper response. \\
- & Cognitivism attempts to build intrinsic motivation by \\
& integrating learning and game experience. \\
- & Player engages in a discovery process through a game \\
& experience that integrates learning and play akin to the \\
& limitations and potentials of the human mind. \\
& - Constructivism provides game challenges that offer the \\
player to solve problems in the game environment. & The challenges can be solved through player's \\
& experiences in previous game levels.
\end{tabular}

\section{Table 3}

\section{$m G B L$ Characteristics}

\begin{tabular}{|c|c|}
\hline $\begin{array}{l}\text { Learning } \\
\text { Theories }\end{array}$ & mGBL Characteristics \\
\hline Behaviourism & $\begin{array}{l}\text { - State objectives and break them down into steps. } \\
\text { - Provide hints or cues that guide players to the desired behaviour. } \\
\text { - Use consequences to reinforce the desired behaviour. } \\
\text { - Provide good feedback and response to the players. }\end{array}$ \\
\hline Cognitivism & $\begin{array}{l}\text { - Organise new game information. } \\
\text { - Link new game information to existing knowledge. } \\
\text { - Use techniques to guide and support learners' attention, } \\
\text { encoding, and retrieval process. } \\
\text { - Provide good screen design, interface and navigation. } \\
\text { - Supply variety of game resources for choices and game options. } \\
\text { - Provide adventures, storyline, and game play. }\end{array}$ \\
\hline Constructivism & $\begin{array}{l}\text { - Pose good problems-realistically complex and personally } \\
\text { meaningful. } \\
\text { - Create group learning activities. } \\
\text { - Model and guide the knowledge construction process. } \\
\text { - Offer different types of game levels. } \\
\text { - Offer great game play and challenges. }\end{array}$ \\
\hline
\end{tabular}


It can be summarised that the characteristics in learning theories should be adopted in the development of mGBL. Behaviourism stresses on the reinforcement and control to the learner by providing good feedback from the game. From the In cognitivism perspective, the game should facilitate the support of transferring, remembering, and recalling knowledge in the learner's memory. From the constructivism approach, the learner should be given opportunities to explore and acquire knowledge that they want.

\section{LEARNING APPROACHES FOR mGBL CHARACTERISTICS}

Various learning approaches have been discussed in the available literature and these approaches originated from the three basic paradigms of behaviour, cognitive and constructive theories. Multiple intelligences theory (Gardner 1983, 1993, 2000), nine events of instructions (Gagne, 1985; Gagne, Briggs, \& Wager, 1992), and problem-based learning are seen to be more of interest to this study and have been applied to many learning environments (Becker, 2006). These theories are discussed in relation to mGBL in this section.

\section{Multiple Intelligences}

Gardner (1983, 1993, 2000) pioneered the nine multiple intelligences theory to account a broader range of human ability. Generally, this theory provides nine potential pathways to learning. It is believed that individuals will naturally learn best under one or more of their intelligences. Therefore, the learning systems should be most effective if different intelligences are incorporated into the learning environment.

In general, the theory of multiple intelligences gives impact to learning in three aspects (Gardner, 2000): (i) curriculum needs to incorporate these intelligences such as arts, self-awareness, communication, and physical education; (ii) instructional methods should appeal to all the intelligences, such as role playing, musical performance, cooperative learning, reflection, visualisation, and story telling; and (3) assessment of learning should measure and take into account the multiple forms of intelligence.

The nine intelligences, as proposed by Gardner, are as follows; i) linguistic intelligence (the ability to master languages-spoken and written), ii) logical-mathematical intelligence (the capacity 
to analyse problems logically and scientifically), iii) interpersonal intelligence (the ability to understand and relate to other people), iv) intrapersonal intelligence (the capacity for understanding oneself), v) spatial intelligence (the ability to know and react to the space), vi) bodily-kinaesthetic intelligence (the capacity for moving around using own body), vii) musical intelligence (skill in the performance, composition, and appreciation of music), viii) naturalist (think through nature and natural forms), and ix) existential (sensitivity to complex issues surrounding our existence, and developed skills in pondering deep questions).

In relation to this study, in order to know how mGBL provides the multi-intelligence approach to learning, Table 4 maps the link between multiple intelligences and mGBL characteristics. Although not all intelligences can be applied in $\mathrm{mGBL}$ at one time, a few are potentially applicable. In fact, mGBL can enggage players deeply by addressing these types of intelligences, where each player has an opportunity to take advantage of his/her own particular strengths (Becker, 2006).

Table 4

Multiple Intelligences Mapped to mGBL Characteristics

\begin{tabular}{|c|c|}
\hline Intelligences & Descriptions \\
\hline 1. Linguistic & $\begin{array}{l}\text { - In a game, the linguistic elements can be in a form of } \\
\text { written words and narrations such as instructions, user } \\
\text { guide and game play. }\end{array}$ \\
\hline $\begin{array}{l}\text { 2. Logical- } \\
\text { mathematical }\end{array}$ & $\begin{array}{l}\text { - Strategy in games is one of the essential features which } \\
\text { needs players to have logical thinking. Solving problems } \\
\text { using mathematical strategy is a good example of this type } \\
\text { of intelligence. }\end{array}$ \\
\hline 3. Interpersonal & $\begin{array}{l}\text { In a game, sometimes players are required to interact with } \\
\text { other players (multi-player) or their own (single player). } \\
\text { Therefore, competition and collaboration might occur to } \\
\text { get the game victory. }\end{array}$ \\
\hline 4. Intrapersonal & $\begin{array}{l}\text { - Challenges in a game encourage players to solve problems } \\
\text { by exploring and interacting within the game. This } \\
\text { interaction might include emotional and mental challenges. }\end{array}$ \\
\hline 5. Spatial & $\begin{array}{l}\text { - Game always gives visual space in various formats such } \\
\text { as colours } 2 \mathrm{D} \text { or } 3 \mathrm{D} \text {. This space makes players interact } \\
\text { actively in the space provided. }\end{array}$ \\
\hline $\begin{array}{l}\text { 6. Bodily- } \\
\text { kinesthetic }\end{array}$ & $\begin{array}{l}\text { - This aspect give players to interact physically in the game } \\
\text { with bodily movement such as hands, fees and other body } \\
\text { parts. }\end{array}$ \\
\hline
\end{tabular}

(continued) 


\begin{tabular}{ll}
\hline Intelligences & \multicolumn{1}{c}{ Descriptions } \\
\hline 7. Musical & $\begin{array}{l}\text { This aspect is important to the game. Audio and music } \\
\text { effects give fun elements to players. The aspect can be in a } \\
\text { form of background music or sound effect. }\end{array}$ \\
8. Naturalist & - $\begin{array}{l}\text { This concept provides the experience with flora and fauna } \\
\text { in a game. Apart from that, the geographical elements } \\
\text { could also be included in this aspect. }\end{array}$ \\
9. Existential & $\begin{array}{l}\text { - Player should feel good and important as a character in a } \\
\text { game world. This aspect provides the responsibility as a }\end{array}$ \\
& "person" in the "game world environment".
\end{tabular}

\section{Nine Events of Instruction}

Gagné (1985) has published a book that identified the mental conditions for learning. From that, Gagne et al. (1992) created a nine-step process called the events of instruction, which correlate to and address the conditions of learning. The nine events of instruction are useful for the instructional designer to develop an effective learning system. These events include, i) gaining attention, ii) informing learners of objectives, iii) stimulating recall of prior learning, iv) presenting the content, v) providing learning guidance, vi) eliciting performance (practice), vii) providing feedback, viii) assessing performance, and ix) enhancing retention and transfer. Table 5 shows the brief descriptions of the nine events of instruction which can be associated with mGBL.

\section{Table 5}

\section{Nine Events of Instruction Linked to $m G B L$}

\begin{tabular}{ll}
\hline Events & \multicolumn{1}{c}{ Descriptions } \\
\hline $\begin{array}{l}\text { 1. Gain } \\
\text { attention }\end{array}$ & $\begin{array}{l}\text { In a game, an attractive introduction screen accompanied } \\
\text { by sound effects or music startles the senses with auditory } \\
\text { or visual stimuli can be included. For example, montage } \\
\text { screen with interesting graphics. }\end{array}$ \\
$\begin{array}{l}\text { 2. Inform } \\
\text { learners of } \\
\text { objectives }\end{array}$ & $\begin{array}{l}\text { The instructions and game rules are provided in game, } \\
\text { as well as objectives of the game to be achieved. These } \\
\text { initiate the internal process of expectancy and motivate } \\
\text { players to complete the game. }\end{array}$ \\
$\begin{array}{l}\text { 3timulate } \\
\text { recall of prior } \\
\text { learning }\end{array}$ & $\begin{array}{l}\text { A simple way to stimulate recall is to challenge players at } \\
\text { different types of game level. The higher is the level, the } \\
\text { harder the task to complete. This process makes players } \\
\text { learn and remember the previous tasks completed in } \\
\text { previous game levels. }\end{array}$ \\
\hline
\end{tabular}

(continued) 


\begin{tabular}{|c|c|}
\hline Events & Descriptions \\
\hline $\begin{array}{l}\text { 4. Present the } \\
\text { content }\end{array}$ & $\begin{array}{l}\text { - This aspect gives players various types of challenges } \\
\text { to know their skills. Game content should be organised } \\
\text { meaningfully. To appeal to different learning modalities, a } \\
\text { variety of challenges should be used if possible. }\end{array}$ \\
\hline $\begin{array}{l}\text { 5. Provide } \\
\text { learning } \\
\text { guidance }\end{array}$ & $\begin{array}{l}\text { - Additional guidance should be provided in a game. } \\
\text { Guidance strategies include the use of examples, user } \\
\text { manual, or tips. A good game is when players do not } \\
\text { refer to the game manual as they can learn easily from the } \\
\text { interface and logic provided. }\end{array}$ \\
\hline $\begin{array}{l}\text { 6. Elicit } \\
\text { performance } \\
\text { (practice) }\end{array}$ & $\begin{array}{l}\text { In a games the players are required to practice new skills to } \\
\text { finish the game. This provides an opportunity for players } \\
\text { to confirm their correct understanding, and the repetition } \\
\text { increases the likelihood of their retention. }\end{array}$ \\
\hline $\begin{array}{l}\text { 7. Provide } \\
\text { feedback }\end{array}$ & $\begin{array}{l}\text { - It is important to provide good feedback in a game. } \\
\text { Feedback in a game can be formed in game actions, } \\
\text { scores, graphics screen, timings and audio. }\end{array}$ \\
\hline $\begin{array}{l}\text { 8. Assess } \\
\text { performance }\end{array}$ & $\begin{array}{l}\text { - Assessment acts as one of the feedback systems in a } \\
\text { game. Each player should be informed of his level of } \\
\text { performance so that he can play until the game ends. }\end{array}$ \\
\hline $\begin{array}{l}\text { 9. Enhance } \\
\text { retention and } \\
\text { transfer }\end{array}$ & $\begin{array}{l}\text { This aspect is provided in a game with various types of } \\
\text { levels. Players need to remember and use their skills to } \\
\text { further play the game. They can use their own strategies } \\
\text { to succeed in the game. }\end{array}$ \\
\hline
\end{tabular}

\section{Problem-Based Learning}

Problem-based learning (PBL) comes from medical education and now it has been widely used in many disciplines at a variety of educational levels. PBL is a learning approach where students are dealt with a problem and challenged to find the solution (Barrows, 1996). Some advantages are, PBL emphasises solving complex problems in rich contexts and promotes higher-order thinking skills (Savery \& Duffy, 1995). PBL makes students take an active, taskoriented, and self-directed approach to their own learning. PBL encourages students to be involved in teamwork and practice their communication skills. It also gives students the problem-solving skills, critical, analytical, and creative thinking skills, as well as individual research skills (Wood, 2003).

According to Barrows (1996), the PBL approach caters for student-centred learning and is related to the constructive approach. He also provided the characteristics of PBL; (i) learning is studentcentred, (ii) focus of learning through authentic problems, (iii) new information is obtained through self-directed learning, (iv) learning 
occurs in small groups, and (iv) teachers are facilitators. The two fundamental principles underlying PBL are: (i) PBL is directly related to constructivist ideas of teaching and learning (Pearson, 2006), and (ii) PBL is promoting learning through social process.

To implement PBL in the learning environment, Merrill (2002) stated that PBL is based upon resolving problems that are encountered in everyday life. As Merrill explained, in PBL practice, students will be guided by the instructor at the early stages, and later, as students gain expertise and become more confident, this guidance is gradually faded. PBL seems to be more effective if students are first introduced to simpler problems, and then gradually to more complex problems, where other learning elements are added to make them more realistic (Merrill, 2002).

In relating the PBL approach to $\mathrm{mGBL}$ design and development, some aspects are analyzed based on mGBL characteristics and features. The analysis (Figure 2) indicates that there are a few aspects of PBL environments that may be utilised to enrich $\mathrm{mGBL}$ elements.

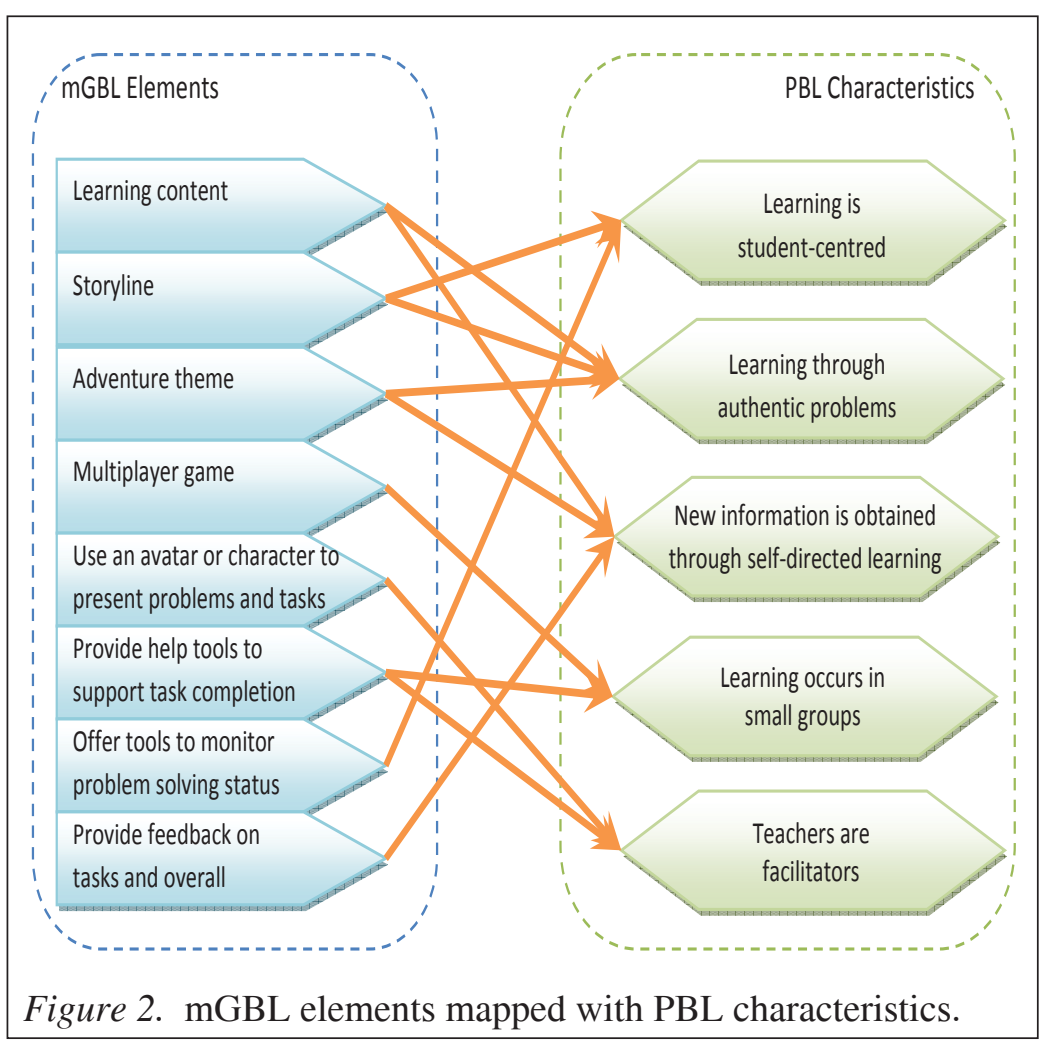




\section{DEVELOPMENT OF 1M'SIA mGBL}

A mGBL application about local content that could foster the concept of 1Malaysia (http://www.1malaysia.com.my) was produced. The game is named 1M'sia, which is abbreviated from One Malaysia. The mGBL development is primarily based on the concept of "edugaming" by Fabricatore (2000), "game-based learning" by Prensky (2001), and "mGBL" by Norshuhada and Syamsul Bahrin (2010); which focuses on intertwining learning and gaming. The characteristics of $1 \mathrm{M}$ 'sia mGBL were adapted from the learning theories and approaches discussed in previous sections. Although not all characteristics are adapted, a few elements are obvious to be implemented as the 1M'sia mGBL characteristics. Such characteristics are illustrated in Table 6.

Table 6

IM'sia mGBL Characteristics

Learning Theories and Approaches

Behaviourist

Cognitivist

Constructive

Multiple Intelligences

Events of Instruction
1M'sia mGBL Characteristics

- In 1M'sia mGBL, objectives are stated and broken down into game steps. The game also provides hints that guide players and give good feedback and responses.

- 1M'sia mGBL provides simple screen design, interface and navigation to successfully run in mobile devices.

- $1 \mathrm{M}$ 'sia mGBL models and guides the knowledge construction process through the game environments. It also offers great game play and simple challenges by learning 1Malaysia values and concepts.

- Four intelligences mainly linguistics, spatial, musical, and existential were adapted in 1M'sia mGBL. The linguistic elements in the form of written words such as instruction, user guide and game play. The 2D space in 1M'sia mGBL makes players interact actively in the space provided. Audio and music effects give fun elements to players. Finally, the player is made to believe that he is the main character of the game.

- All nine events of instruction were adapted in the 1M'sia mGBL. The game starts with gaining player attention by providing an attractive introduction screen accompanied by sound effects. The game ends with the assessment marks or game score. 
The mGBL developed for this study was implemented using the Flash tool. Four design and development phases were involved, adapted from Syamsul Bahrin and Norshuhada (2009) as seen in Figure 3: (i) analysis (ii) game design (iii) development, production, and integration; and (iv) evaluation. In the analysis phase, the target user is defined as ranging from nine years old to adult. Besides, the mobile technology and restrictions were analysed for the targeted platform. The most important aspect is the learning content analysis. The values of 1Malaysia concept were chosen for the learning content of the mGBL.

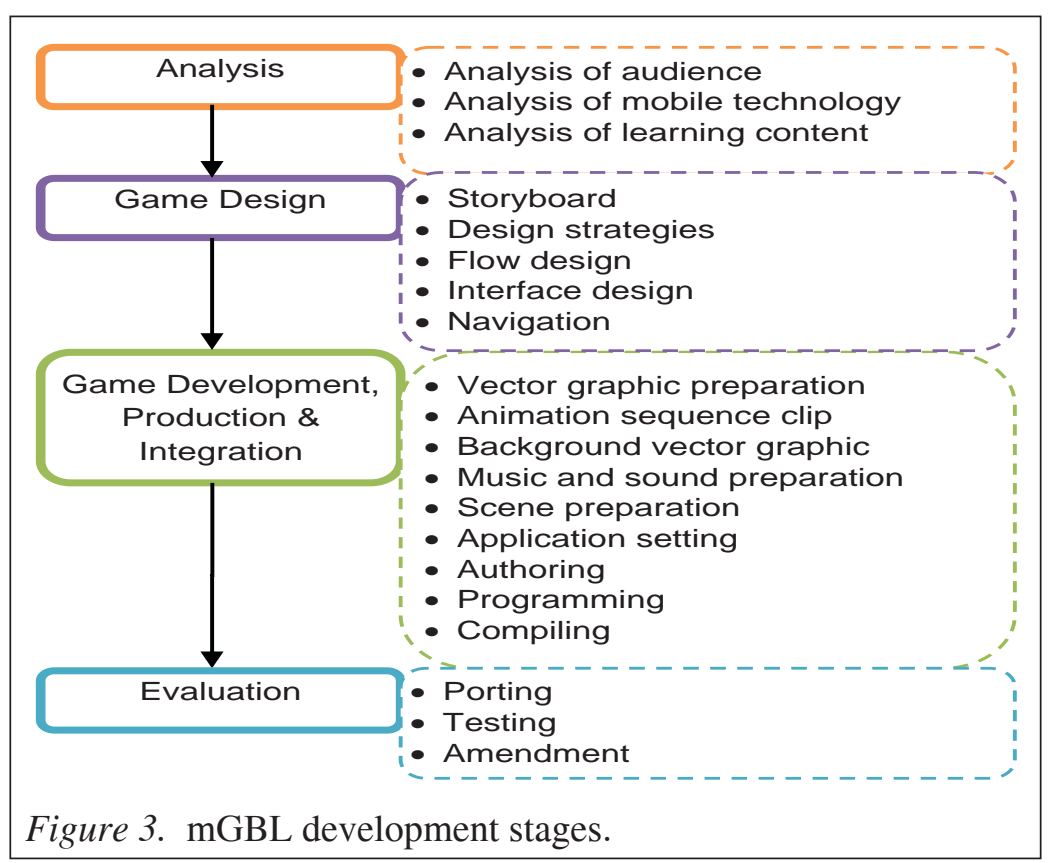

In the game design phase, a group of activities were conducted, such as storyboarding, game flow designing, interface designing, and navigation structure designing. From here, the real development phase would then take place. In the development phase, all game sources was integrated through authoring and programming steps using Flash tool. The game sources included vector images and graphics, text, sound, and music, which provide the learning content. In the final phase, the game was tested for verification to ensure that the game is playable using the mobile phone without errors and bugs. Amendments were made for any errors that occurred during testing. Lastly, the game was fully deployed in the mobile phone and available for playing. 


\section{Learning Content of 1M'sia mGBL}

Malaysian local content is urgently required especially for education, entertainment, and games (Norshuhada and Syamsul Bahrin, 2010). Thus, an mGBL application about local content that could foster the concept of 1Malaysia was produced. The mGBL can subtly assist users in learning useful information that the values of 1Malaysia are conveying. This is necessary for the succes of promoting harmonious and unity amongst the multi-ethnic citizens of Malaysia.

The 1Malaysia formula was conceptualised for implementation in two main aspects. The first was through the assimilation of the (i) principles of unity, while the second aspect was the assimilation of (ii) aspirational values. Such values that were incorporated in the mGBL:

- Principles of Unity

o Acceptance amongst all races and people of Malaysia. The game shows how to shake hands with different races.

o Humility in forming decisions and actions. The game shows the importance of queuing in public places to get services.

o Mutual respect for others. The game guides the players to know and respect other cultures as well as elderly people.

- Aspirational Values

0 Integrity in all matters and transactions. The game portrays responsibility on tasks or jobs.

o Culture of education. The game shows correct and incorrect rules in school.

o Culture of precision in terms of time management and improving efficiency. The game demonstrates time management policy.

\section{M'sia Game Play and Flow}

The values of 1Malaysia that were incorporated in the mGBL content provide the basis of the mGBL play rules and actions. In general, the game is generated into two game plays which are simple quiz and mix-and-match. A player acts as a Malay character and then is triggered with several situations which provide the 1Malaysia values. Such situations are an ATM, a traditional costume shop, a house, a group of people, a school, and religious places. The player then has to enter the situation for the game environment. The player's skills and knowledge will determine how well he is able to do the right things, and the values will either be mastered or not. Figure 4 shows the 1M'sia game flow. 


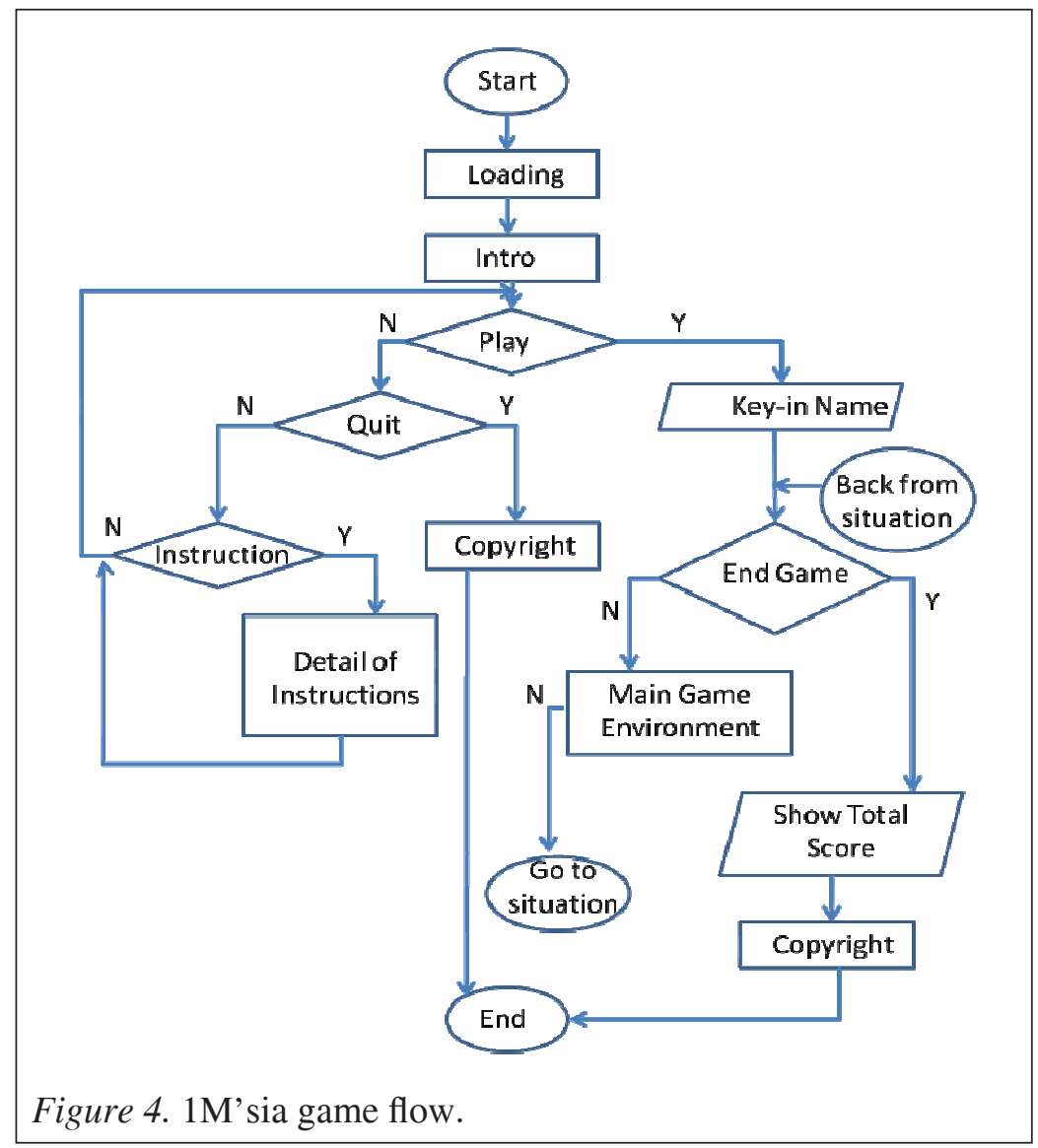

At the end of the main game environment, the player is shown his level score of his 1 Malaysia concept comprehension. If the score is more than $70 \%$, the player is stated as having adequate comprehension of the concept. Otherwise, the player can try again to achieve an acceptable level of comprehension.

\section{M'sia mGBL Screen Shots}

The following screen shots (Figure 5 to 12) depict the user interface and screens of the 1M'sia mGBL. At first when the game is loaded, the main page is displayed. Players can continue to start playing the game by pressing start button or selecting other buttons for instructions. The game will start at the main game environment, and players can control the game by pressing the arrow and selection keys. 
Figure 5 shows the main environment of the 1M'sia mGBL. Figure 6 and 8 are examples of situations that will be triggered. For example in Figure 6, when a player enters the situation, a short animation will be displayed that shows the $1 \mathrm{M}$ 'sia value and then a simple quiz is presented. The example shown in Figure 7 is a humility quiz. Once the answer is selected, the score will be shown. After that the player will get back to the main environment to proceed to the next situations provided in the main game environment.

Figure 8, 9, and 10 show an example of a mix-and-match game where the player needs to match the correct traditional costumes for the specific ethnic group in Malaysia. The game immediately informs the player whether the answer is right or wrong. Figure 11 shows the school rules game that requires a player to collect as many correct rules as possible. On Figure 12, a simple summary is given at the end of the game, where the player is informed of his total percentage achieved. The percentage indicates the level of player comprehension of 1Malaysia values.

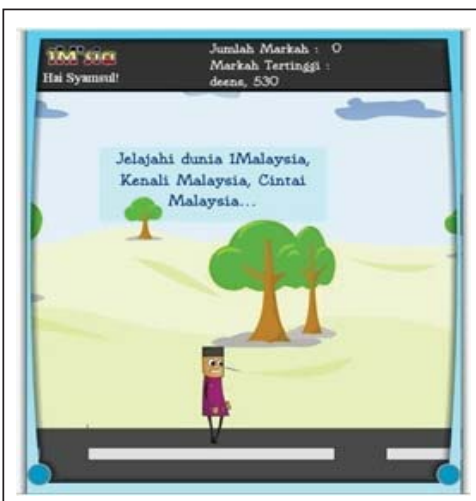

Figure 5. Main environment of 1M'sia .

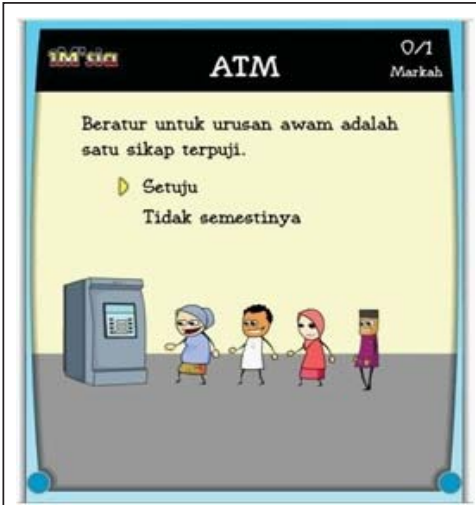

Figure 7. Simple quiz.

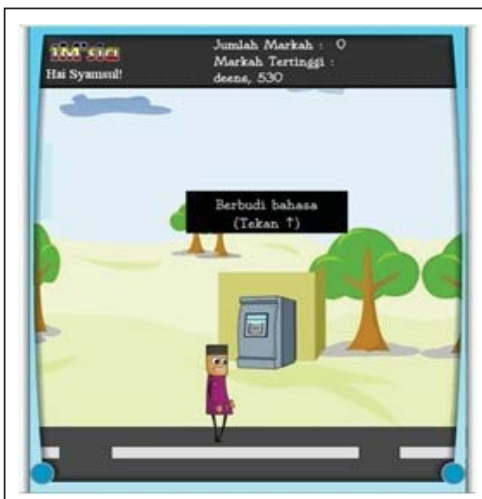

Figure 6. Situation and value in 1M'sia.

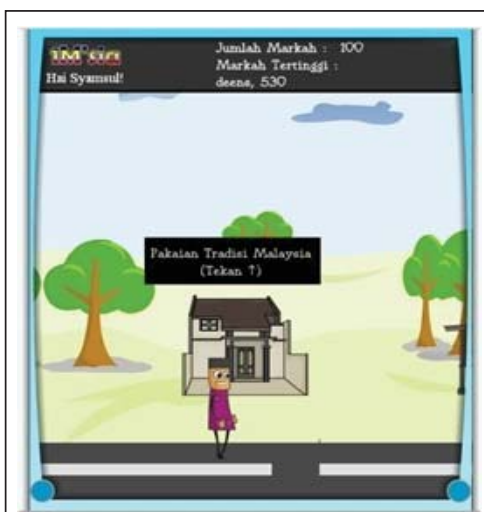

Figure 8. Traditional costume store. 

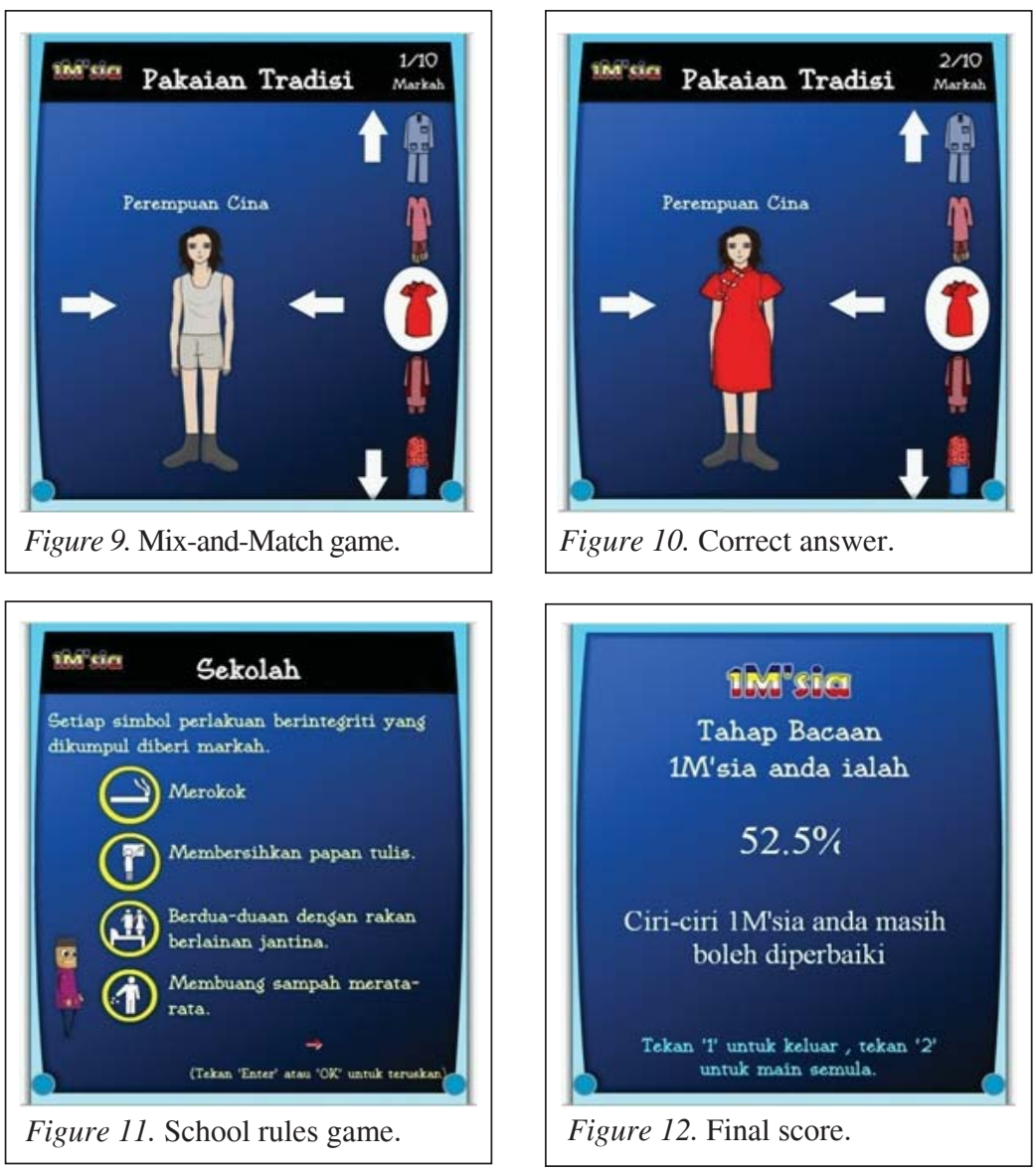

\section{Porting and Testing of 1M'sia mGBL}

The final mGBL development stages usually involved porting and testing. Porting is making changes to the game in order to make it run on a different environment. Testing a game is mandatory in ensuring there is no crash or inconvenience for players. The game testing was conducted in following the dimensions adapted by Norshuhada and Syamsul Bahrin (2010). They categorised the testing into five dimensions:

i. Functionality - does the game function correctly? Are multimedia elements of good quality?

ii. Compliance - does the game follow the standard error message handling? Does it fulfil a particular content rating?

iii. Compatibility - can the game be played on different devices/ platforms or different device specifications? 
iv. Localisation - is it suitable for different countries and languages?

v. Soaking - is the game stable when left to run for a period of time?

Overall, the technical game testing was successfully conducted. As a result, the game runs properly and it contains no major errors. Nevertheless the mGBL is only compatible with the PDA and smart phone. The main objective of testing was achieved by showing that the game is playable on certain mobile devices.

\section{HEURISTICS EVALUATION STRATEGY FOR mGBL}

Heuristics evaluation is developed for evaluating the effectiveness of an application. In fact, this kind of evaluation is commonly applied in usability evaluation. A usability evaluation is conducted on users in order to find out how the users can easily and efficiently reach the application objectives. There are many usability evaluation methods; most were originally developed by Nielsen and Molich (1990), and Nielsen (1993). In fact, the most utilised and useful usability heuristics was proposed by Nielsen (Nielsen, 1994; Muller, M. Claid, Bell, Dooley, Meiskey, Meskil, Spaiks \& Tellam, 1995). These heuristics however are more focused on the general applications and are not specific to games. Malone created the first heuristics for evaluating educational games (Malone, 1980).

In addition to not being developed for evaluating $\mathrm{mGBL}$, the existing heuristics do not deal with mobility issues and do not cover learning content evaluation. Therefore, in evaluating the $1 \mathrm{M}$ 'sia mGBL, a set of heuristics were adapted from Korhonen and Koivisto (2006), and Koivisto and Korhonen (2006) by adding a new component that deals with learning content and context in mGBL. In particular, the heuristics evaluation strategy used in this study consists of four components: game usability (GU), mobility (MO), game play (GP), and learning content (LC). The GU components (Table 7) depict the interface and game controls which the player interacts with the game. Game interface allows a player to play smoothly and react based on user actions. In general, good game usability ensures that the player has interest to play the game until the end. 


\section{Table 7}

Game Usability Components (Korhonen \& Koivisto, 2006)

\begin{tabular}{lll}
\hline Number & Game Usability Components & \multicolumn{1}{c}{ Descriptions } \\
\hline GU1 & $\begin{array}{l}\text { Audio-visual representation } \\
\text { supports the game }\end{array}$ & $\begin{array}{l}\text { The game should look visually appealing. } \\
\text { All graphics and audio should support } \\
\text { game play and story; consistent and }\end{array}$ \\
& & $\begin{array}{l}\text { informative to player. }\end{array}$
\end{tabular}

GU2 Screen layout is efficient and The screen design should present all visually pleasing necessary information to player and follow the general principles of good screen layout design.

GU3 Device user interface (UI) The player interacts properly with the and game UI are used for game user interface and device functions. their own purposes

GU4 Navigation is consistent, logical, and minimalist Full-screen mode is preferable.

All buttons and navigations should be organised reasonably, provide more clarity and easy to remember. The navigation should also be intuitive and natural.

GU5 Control keys are consistent

Standard control keys can be used since and follow standard conventions

GU6 Game controls are convenient and flexible the player already knows from other games played.

The game controls can be customised. The controls also should be designed based on device's capacities.

GU7 The game gives feedback on the player's actions

It is preferred if game user interface has a quick response on player's actions. The feedback can be presented in graphics, audio, or be tactile.

GU8 The player cannot make irreversible errors

The game should provide confirmation message for actions that can cause serious and permanent damage. Recovery is allowed when mistakes happen.

GU9 The player does not have to memorise things unnecessarily

Minimum memory should be used minimumly. Game user interface design and challenges are considered in this aspect.

GU10 The game contains help

The game provides instructions to player for playing the game. It is unnecessary for player to read manuals frequently.

In Table 8, the MO components concern issues that affect mobility of the game. Mobility can be defined as the ease of a player to enter to the game world and the accessibility of the game anywhere and anytime. 
Table 8

Mobility Components (Korhonen \& Koivisto, 2006)

\begin{tabular}{cll}
\hline Number. & \multicolumn{1}{c}{ Mobility Components } & \multicolumn{1}{c}{ Descriptions } \\
\hline MO1 & $\begin{array}{l}\text { The game and play } \\
\text { sessions can be started } \\
\text { quickly }\end{array}$ & $\begin{array}{l}\text { The game sessions can be started quickly } \\
\text { and easily, preferably in less than five } \\
\text { seconds. There is a possibility to skip the } \\
\text { game introduction. }\end{array}$ \\
MO2 & $\begin{array}{l}\text { The game accommodates } \\
\text { with the surroundings }\end{array}$ & $\begin{array}{l}\text { Mobile games are played everywhere and } \\
\text { this should accommodate the surroundings. } \\
\text { The game audio volume can be conveniently } \\
\text { adjusted or muted. The game should also put } \\
\text { up with the device settings for instance, in } \\
\text { silent mode. }\end{array}$ \\
MO3 & $\begin{array}{l}\text { Interruptions are handled } \\
\text { reasonably }\end{array}$ & $\begin{array}{l}\text { Intessages are allowed during the play } \\
\text { session. It is possible for the player to pause } \\
\text { the game at any time and continue to play } \\
\text { later. }\end{array}$ \\
\hline
\end{tabular}

The 10 GP components (Table 9) describe how the game is playable, runs smoothly and consistently, is meaningful, and is not boring for the player. The GP is important because it is dynamic and occurs when the player interacts with the game mechanics and rules.

\section{Table 9}

\section{Game Play Components (Korhonen \& Koivisto, 2006)}

\begin{tabular}{lll}
\hline Number & Game Play Components & \multicolumn{1}{c}{ Descriptions } \\
\hline GP1 & $\begin{array}{l}\text { The game provides clear } \\
\text { goals or supports player } \\
\text { created goals }\end{array}$ & $\begin{array}{l}\text { The game goals are provided clearly because } \\
\text { having a clear goal in player's mind is the } \\
\text { core of an enjoyable experience. The goals } \\
\text { can be either short-term or long-term goals. }\end{array}$
\end{tabular}

GP2 The player sees the progress in the game and can

The game provides the game progress. The compare the results progress can be showed as high-score lists, rankings, character levels, or different titles.

GP3 The players are rewarded The game should provide rewards as a and rewards are meaningful player progresses in the game. It should be meaningful for the player and should be adjusted to the challenge.

GP4 The player is in control

The player should know what is happening in the game world. The player will be able to decide on actions they have to take for continuing in the game world. 


\begin{tabular}{|c|c|c|}
\hline Number & Game Play Components & Descriptions \\
\hline GP5 & $\begin{array}{l}\text { Challenge, strategy, and } \\
\text { pace are in balance }\end{array}$ & $\begin{array}{l}\text { The game should not bore the player and } \\
\text { he can choose the difficulty level. All game } \\
\text { strategies and pace can be adjusted to the } \\
\text { player's preference. }\end{array}$ \\
\hline GP6 & $\begin{array}{l}\text { The first-time experience } \\
\text { is encouraging }\end{array}$ & $\begin{array}{l}\text { The game can create a good first impression } \\
\text { of the game within the first five minutes. } \\
\text { Completing first play session should make } \\
\text { the player want to play the next play session. }\end{array}$ \\
\hline GP7 & $\begin{array}{l}\text { The game story supports } \\
\text { the game play and is } \\
\text { meaningful }\end{array}$ & $\begin{array}{l}\text { The player can make his own decision in the } \\
\text { game. The story is meaningful and fits with } \\
\text { the game elements. }\end{array}$ \\
\hline GP8 & $\begin{array}{l}\text { There are no repetitive or } \\
\text { boring tasks }\end{array}$ & $\begin{array}{l}\text { Task repetition without changing any } \\
\text { conditions is not advised. This will give } \\
\text { boring tasks to players. }\end{array}$ \\
\hline GP9 & $\begin{array}{l}\text { The game does not } \\
\text { stagnate }\end{array}$ & $\begin{array}{l}\text { The player must know that the game } \\
\text { progression and the game ending session } \\
\text { should be clearly indicated. There is also a } \\
\text { possibility of starting the game again. }\end{array}$ \\
\hline GP10 & The game is consistent & $\begin{array}{l}\text { Consistency in the game world is important } \\
\text { The game actions, flow, and design should } \\
\text { work in a consistent and logical way. }\end{array}$ \\
\hline
\end{tabular}

Lastly, the LC components (Table 10) is specifically concentrated on the learning content. The learning content should provide informative, useful, and understandable content to users when playing the mGBL.

\section{Table 10}

\section{Learning Content Components}

\begin{tabular}{lll}
\hline No. & Learning Content Components & \multicolumn{1}{c}{ Descriptions } \\
\hline LC1 & The content can be learned \\
easily & $\begin{array}{l}\text { The game should provide an easy learn- } \\
\text { ing content, that is not too complicated as } \\
\text { preferable for the intended users. }\end{array}$
\end{tabular}

LC2 The game provides learning The game provides learning content, so content that the users learn new knowledge from the game. It could be any information that is of interest to the users.

LC3 The learning objective from The learning objective from the game is the game is achieved achieved after the game ends.

LC4 The content is understandable The learning content is easy to understand and as expected by the users. 


\section{Evaluation Sessions and Methods}

In order to evaluate the perception of users about 1M'sia mGBL, the proposed heuristics evaluation strategy was used. Although in practice, heuristics method relies on experts as the respondents (Korhonen, \& Koivisto, 2006), in this study the heuristics are utilised firstly, to design the mGBL based on those heuristics, and secondly, to use the heuristics as items in a survey instrument. The methods as implemented in Norshuhada and Syamsul Bahrin (2010) were adapted, where the evaluation actually took place in a natural setting while users play the mGBL. In addition, these methods have a better sense of users without having any formal circumstances. The evaluation sessions were conducted in October 2009 during the International Exposition of Research and Inventions of Institutions of Higher Learning 2009 (PECIPTA 2009) in Kuala Lumpur. Visitors who came to our booth were randomly asked to play the 1M'sia mGBL and at the end of the three-day expo, 80 visitors tried the mGBL. All visitors played the mGBL using the devices that were provided. The questions were based a on five-point Likert scale (5: strongly agree, 4: agree, 3: neither agree nor disagree, 2: disagree, 1: strongly disagree) and were based on the four components of the heuristics evaluation strategy-game usability, game mobility, game play, and learning content (as described in Table 7 to 10). A five-point Likert scale was adopted, Brace (2004) suggested these response classifications: (i) if the response is 1.00 to 1.80 , it is classified as highly low; (ii) if the response is 1.81 to 2.60 , it is classified as low; (iii) if the response is 2.61 to 3.40 , it is classified as moderate; (iv) if the response is 3.41 to 4.20 , it is classified as high and (v) if the response is 4.21 to 5.00, it is classified as highly high.

\section{FINDINGS AND DISCUSSION}

Some of the salient findings of the heuristics evaluation strategy are presented in this section. The discussion is intended to highlight the main findings that arise from the responses obtained. Firstly, the demographic profile of the participants was as illustrated in Table 11. Eighty participants were selected as respondents to the study. Their age ranged from 9 to 17 years old, i.e., the targeted users of the 1M'sia mGBL. Out of the 80 users, $45 \%$ of the respondents were male and the remainder female. In age range, the majority of the respondents were 13 and above $(71.25 \%)$, and most of them aged 16 $(25 \%)$. Figures 11 to 13 show the evaluation session taking place at the expo. 
Table 11

Demographic Profile

\begin{tabular}{lrrrr}
\hline \multirow{2}{*}{ Ages } & \multicolumn{3}{c}{ Gender } & \multirow{2}{*}{ Total } \\
\cline { 3 - 4 } & 9 & Male & Female & \\
\hline & 3 & 2 & 5 \\
& 10 & 4 & 2 & 6 \\
& 11 & 2 & 3 & 5 \\
& 12 & 2 & 5 & 7 \\
& 13 & 4 & 8 & 12 \\
& 14 & 6 & 4 & 10 \\
& 15 & 2 & 3 & 5 \\
& 16 & 7 & 13 & 20 \\
& 17 & 6 & 4 & 10 \\
\hline Total & & 36 & 44 & 80 \\
\hline
\end{tabular}

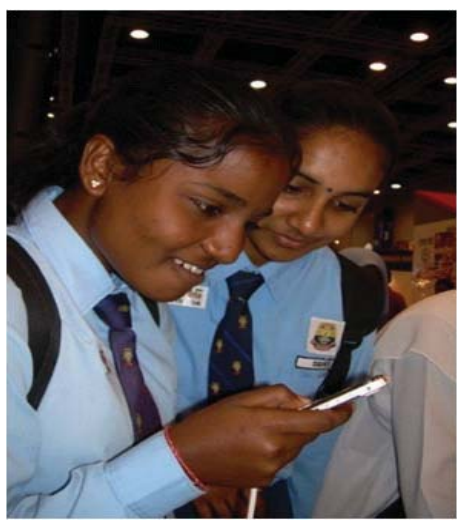

Figure 11. Users playing 1'Msia mGBL.

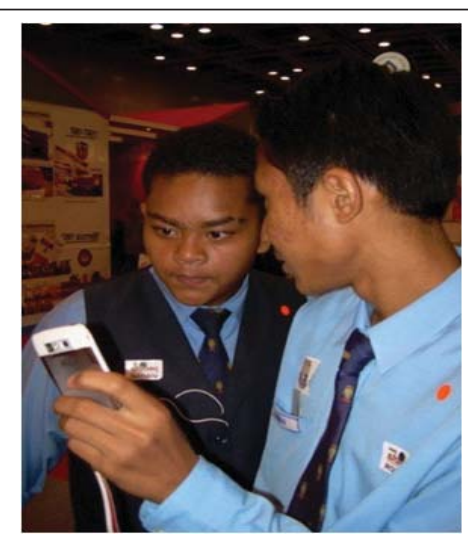

Figure 12. Users playing 1'Msia mGBL.

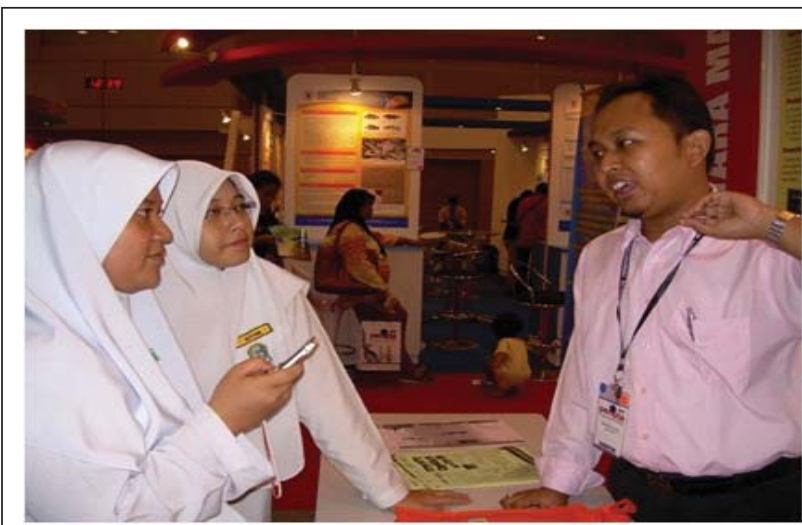

Figure 13. Conducting the evaluation. 
The first component of the evaluation was game usability. The overall mean was 3.7 and the highest score was GU6 (Game controls are convenient and flexible). Figure 14 depicts the scores. In general, the results showed that the usability aspects of the 1M'sia mGBL is relatively high.
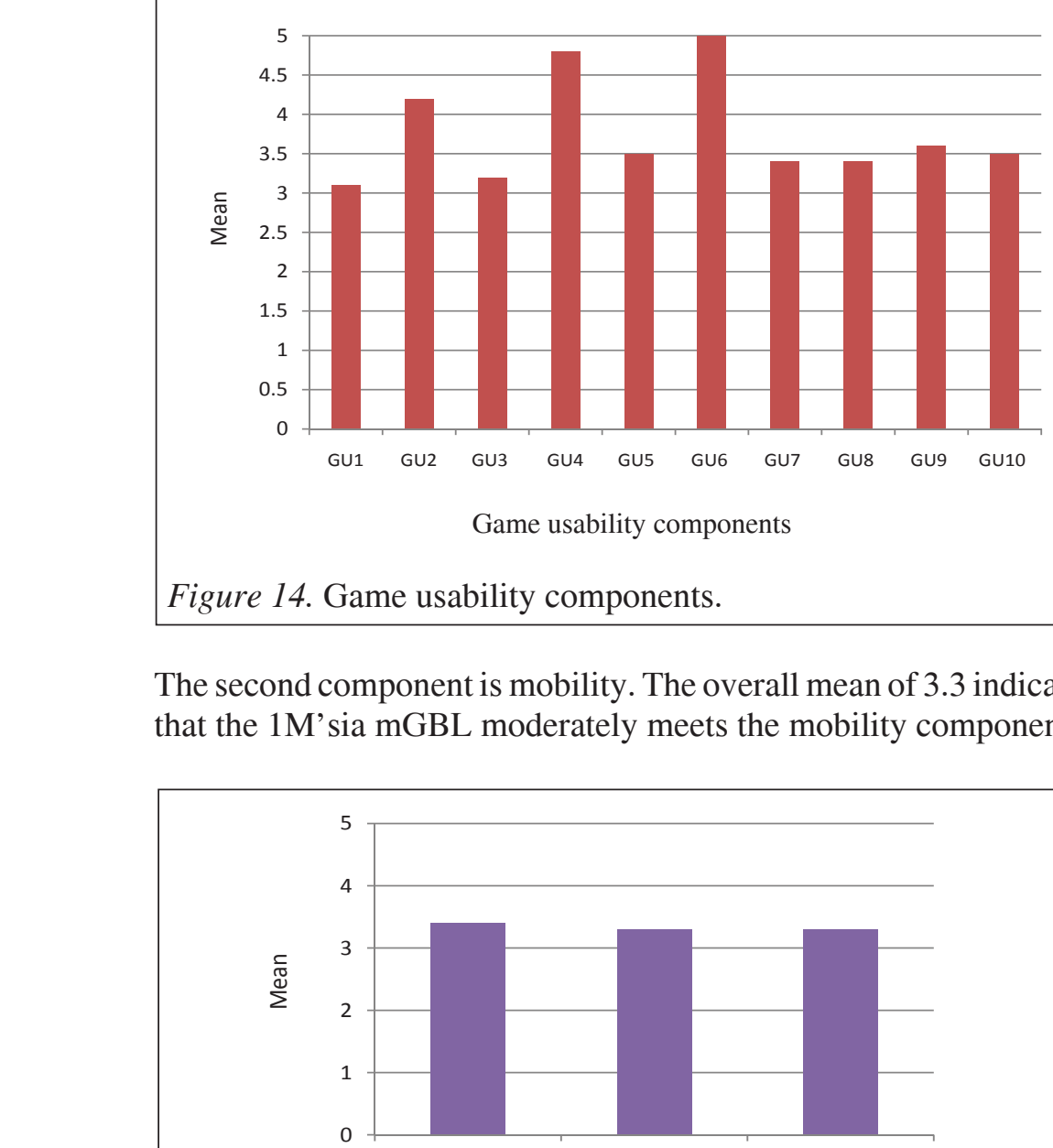

Figure 14. Game usability components.

The second component is mobility. The overall mean of 3.3 indicated that the $1 \mathrm{M}$ 'sia mGBL moderately meets the mobility components.

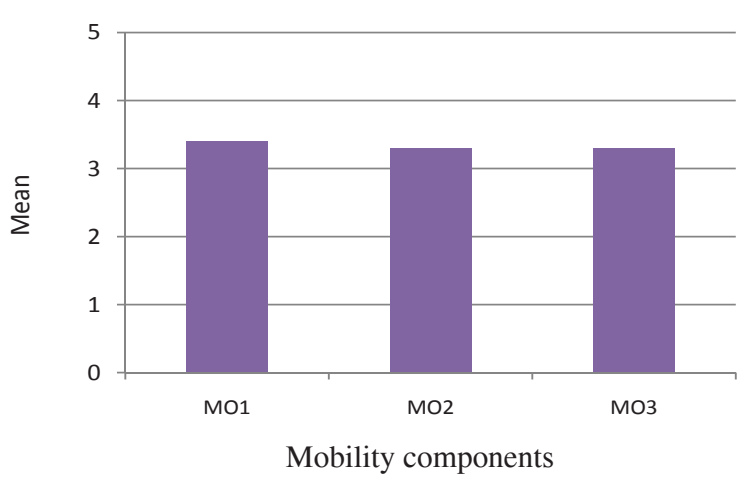

Figure 15. Mobility components.

The next component is game play. The overall mean was 3.6, indicating a high response. The highest score was GP4 (The player is in control) and the lowest was GP6 (The first-time experience is 
encouraging). Figure 16 depicts these values. Based on the overall mean, it can be concluded that the respondents agreed that the game provided clear goals, rewards included were meaningful, the player was in control, and challenges and pace were in balance. Although this was the case, the respondents felt that first-time experience, repetitiveness of tasks, stagnation and consistency of game were at the moderate level.

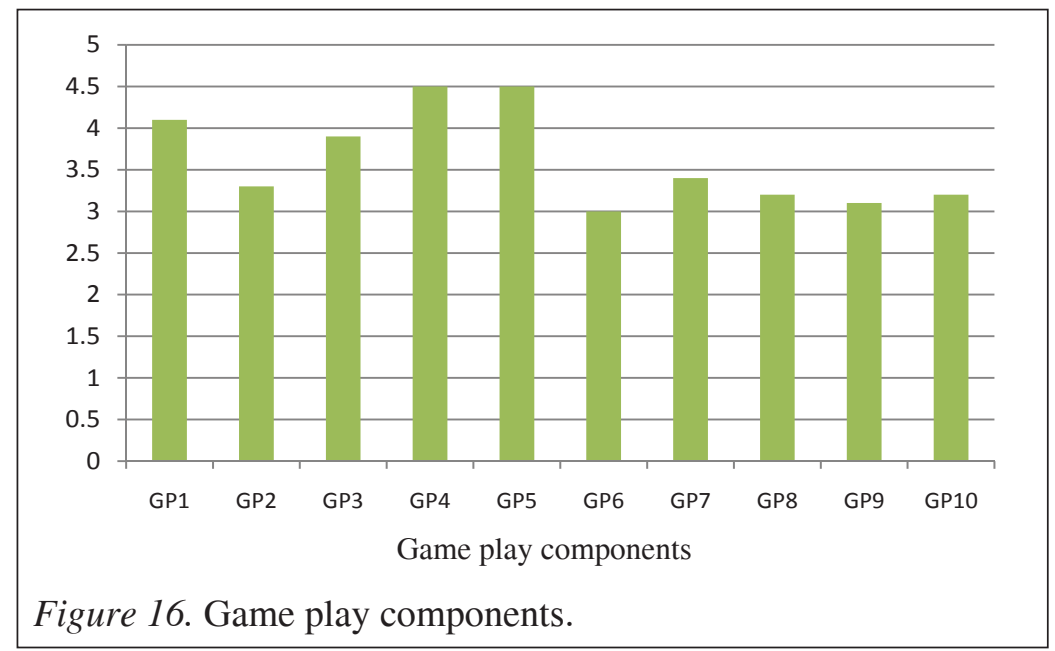

The component that is important for learning objective is the learning content (Figure 17). The overall mean of 4.0 indicated that the learning content was highly informative, understandable, and easy to learn. The highest score was LC4 (The content is understandable). However, the respondents felt that the learning content moderately interested them, suggesting that the $1 \mathrm{M}$ 'sia concept just moderately captured their interest.

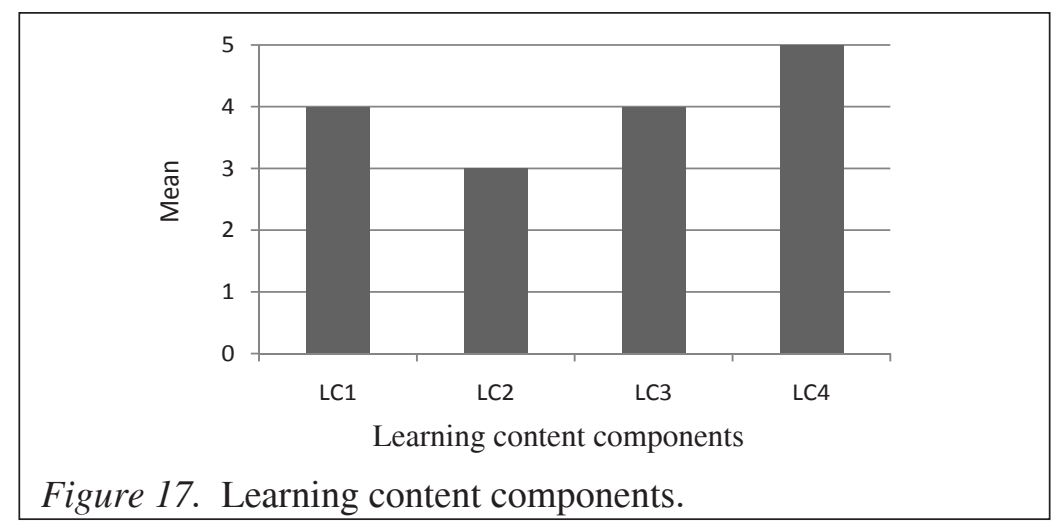




\section{CONCLUSION}

This study portrays a mapping between some learning theories and approaches to mGBL characteristics. Having these mGBL characteristics, the mGBL application was developed specifically for Malaysian local content. The study also briefly described the design and development process and suggested that key design decisions are strengthened by application of theory in the learning sciences. The development stages adapted into the mGBL development were successfully implemented, simple to follow, and provided an easy guideline for a developer to develop a similar concept of mGBL. In this respect, this may be of interest to fellow game developers.

As a general rule, heuristics evaluation was proposed for evaluating how usable an application is to the users. However, from the literature, current heuristics evaluations are not really feasible to be implemented for mGBL because of the mobility aspects, game features, and learning content issues. Therefore, in this study, a heuristics evaluation strategy was developed for evaluating the effectiveness of mGBL application, with respect to game usability, game mobility, game play, and learning content (as listed in Table 7 to 10$)$.

In order to analyse these aspects, $1 \mathrm{M}$ 'sia mGBL was used for conducting the evaluation sessions using the proposed strategy. Overall, the evaluation sessions were successfully conducted even though heuristics evaluation is not intended for end-users.

Prospective work can be recommended for this study, for example the heuristics evaluation strategy should be extended to include further data analysis such as hypothesis testing and correlation analysis. The analyses can perhaps provide more accurate findings and discussions. In addition, the evaluation strategy can be conducted on other mGBL applications. Although the mGBL application was developed to comply with several theories, a future study could consider other theories in the design of mGBL.

In conclusion, the objective of this study to structurally develop the mGBL, which would contribute to the current demand for local content production, was successfully accomplished. Furthermore, all research questions put forward were answered; the characteristics of the mGBL were identified, the current practices in the mGBL development process were analysed, and the evaluation process and related dimensions were soundly established. 


\section{REFERENCES}

Barrows, H. S. (1996). Problem-based learning in medicine and beyond: A brief overview. New Directions for Teaching and Learning, 68, 3-12.

BBC-Bitesize (2008). GCSE Bitesize programme for schools. Retrieved June 18, 2007, from http://www.bbc.co.uk/schools/ gcsebitesize/games/.

Becker, K. (2006). Pedagogy in commercial video games. In D. Gibson, C. Aldrich, \& M. Prensky (Eds.), Games and simulations in online learning: Research and development frameworks. Place idea Group Inc.

Brace, I. (2004). Questionnaire design. London: Kogan Page.

Chen, Y. S., Kao, T. C., Yu, G. J. \& Sheu, J. P. (2004). A mobile butterfly-watching learning system for supporting independent learning. Proceedings of the 2nd International Workshop on Wireless and Mobile Technologies in Education. Taiwan.

Collella, V. (2000). Participatory simulations: Building collaborative understanding through immersive dynamic modeling. Journal of the Learning Sciences, 9(1), 471-500.

Dufresne, R. J., Gerace, W. J., Leornard, W. J., Mestre, J. P. \& Wenk, L. (1996). Classtalk: A classroom communication system for active learning. Journal of Computing in Higher Education, 7, 3-47.

Egenfeldt-Nielsen, S. (2006). Overview of research on the educational use of video games. Digital Kompetanse, 1(3), 184-213.

Fabricatore, C. (2000). Learning and Videogames: An unexploited synergy. Retrieved June 18, 2007, from http://www.learndev. org/d1/FabricatoreAECT2000.PDF

Gagné, R. M., Briggs L. J., \& Wager W.W. (1992). Principles of instructional design (4th ed.). Fort Worth, Texas: Harcourt Brace Jovanovich College Publishers.

Gardner, H. (1983). Frames of mind: The theory of multiple intelligences. New York: Basic.

Gardner, H. (1993). Multiple intelligences: The theory in practice. New York: Basic.

Gardner, H. (2000). Intelligence reframed: Multiple intelligences for the 21st Century. New York: Basic.

Goodman, D., Bradley, N. L., Paras, B., Williamson, I. J., \& Bizzochi, J. (2006). Video gaming promotes concussion knowledge acquisition in youth hockey players. Journal of Adolescence, 29, 351-360. 
IGDA (2005). Mobile game white paper. International Game Developers Association, Game Developers Conference. Retrieved June 18, 2007 from http://www.igda.org/online/ IGDA_Mobile_Whitepaper_2005.pdf

International telecommunication Union (ITU) (2008). World telecommunication/ICT indicators database 2008. Retrieved June 18, 2007, from http://www.itu.int/ITU-D/ict/publications/ world/world.html

Kang, S. (2004). Instructional design and development: A brief historical overview. Educational Technology, 44(6), 39-45.

Kettanurak, V., Ramamurthy K., \& Haseman, W. (2001). User attitude as a mediator of learning performance improvement in an interactive multimedia environment: An empirical investigation of the degree of interactivity and learning styles. International Journal Human-Computer Studies, 54, 541-583.

Klopfer, E., \& Squire, K. (2002). Games-to-teach. Proceedings of the MIT Workshop at the International Conference of the Learning Sciences. Seattle, WA.

Korhonen, H., \& Koivisto, E. M. I. (2006). Mobile entertainment: Playability heuristics for mobile games. Proceedings of MobileHCI. ACM Press.

Krenn, B., Böhme, A., \& Mitchell, A. (2008). Fastest first! and crisis! Creating innovative mobile learning games on the basis of quiz templates. Proceedings of Serious Games on the Move International Conference. Cambridge.

Lee, J., Luchini, K., Michael, B., Norris, C., \& Soloway, E. (2004). More than just fun and games: Assessing the value of educational video games in the classroom. Proceedings of the CHI '04 Conference on Human Factors in Computing Systems. Vienna, Austria.

Lonsdale, P., Baber, C., \& Sharples, M. (2004). Engaging learners with everyday technology: A participatory simulation using mobile phones (pp. 461-465). Proceedings of the Mobile Human-Computer Interaction. Heidelberg: Springer.

Malone, T. W. (1980). Heuristics for designing enjoyable user interfaces: Lessons from computer games. Proceedings of the 3rd ACM SIGSMALL Symposium and the first SIGPC Symposium, 162-169.

McAlister, M. J., \& Xie, P. H. (2005). Using a PDA for mobile learning. IEEE International Workshop on Wireless and Mobile Technologies in Education, 282-284. 
Malaysian Communications and Multimedia Commission (MCMC) (2009). Facts and Figures. Retrieved Feb 20, 2009, from http://www.skmm.gov.my/facts_figures/stats/index.asp

Merrill, M. D. (2002). A pebble-in-the-pond model for instructional design. Performance Improvement, 41(7).

Mitchell, A. (2003, May). Exploring the potential of a gamesoriented implementation for m-Portal. Proceedings of the MLEARN 2003 conference - learning with mobile devices. London, UK.

Mitchell, A., \& Savill-Smith, C. (2004). The use of computer and video games for learning. A review of the literature. London: LSDA.

Mitchell, A., Inchingolo, P., Vatta, F., Gricar, J., Cisic, D., Petrovic, O., Kittl, C., \& Peyha, H. J. (2006). Mobile game-based learning to promote decision-making skills-a pan-European project. Proceedings of the EURO mGOV Conference.

Mohamudally, N. (2006, November). A massive multiplayer game framework for mobile learning. Proceedings of the Fourth IEEE International Workshop on Wireless, Mobile and Ubiquitous Technology in Education (WMUTE '06) 23-25.

Muller, M. J., McClard, A., Bell, B., Dooley, S., Meiskey, L., Meskill, J. A., Sparks, R., \& Tellam, D. (1995). Validating and extension to participatory heuristic evaluation: Quality of work and quality of work life. Proceedings of Computer Human Interaction, 115-116.

Naismith, L., Lonsdale, P., Vavoula, G., \& Sharples, M. (2006). Literature review in mobile technologies and learning. Futurelab. Technical Report 11. Retrieved June 18, 2007 from http://www.futurelab.org.uk/resources/documents/lit_ reviews/Mobile_Review.pdf.

Nielsen, J. (1993). Usability engineering London. Academic Press.

Nielsen, J. (1994). Enhancing the explanatory power of usability heuristics. Proceedings of Computer Human Interaction, 152-158.

Nielsen, J., \& Molich, R. (1990). Heuristic evaluation of user interfaces. Proceedings of Computer Human Interaction, 249-256.

Shiratuddin, N., \& Zaibon, S. B. (2010). Mobile games based learning (mGBL) with local content and appealing characters. International Journal of Mobile Learning and Organisation, (4) $1,55-82$ 
Pachler, N. (Ed.) (2007). Mobile learning: Towards a research agenda. WLE Centre Occasional Papers in Work-based Learning, Institute of Education. Technical Report 11. Retrieved June 18, 2007, from http://www.futurelab.org.uk/ resources/documents/lit_reviews/Mobile_Review.pdf.

Pearson, J. (2006). Investigating ICT using problem-based learning in face-to-face and online learning environments. Computers and Education, 47(1), 56-73.

Pelkonen, T. (2004). Mobile games. E-Content Report 3, ACTeN. Retrieved on June, 18 2007, from http://www.acten.net/ uploads/images/382/IR3_010304-2.pdf.

Pivec, M. (2005). The benefits of game-based learning. Retrieved June 18, 2007, from http://www.elearningeuropa.info/index. php?page $=$ doc $\&$ doc $\_$id $=6456 \&$ doclng $=3 \& \operatorname{lng}=$ en

Prensky, M. (2001). Digital game-based learning. New York: McGraw-Hill.

Proctor, N., \& Burton, J. (2003). Tate modern multimedia tour pilots 2002-2003. In J. Attewell, Da Bormida, M., Sharples, \& Savill-Smith, C. (Eds.), Proceedings of the M-Learn 2003: Learning with mobile devices (pp. 54-55). London.

Rieber, L. P. (1996). Seriously considering play: Designing interactive learning environments based on the blending of microworlds, simulations, and games. Educational Technology Research and Development, 44(2), 43-58.

Roslan, M. (2007). Incentives for Malaysian content development, Putrajaya: Content and industry development MyICMS, technology, and standard division. Suruhanjaya Komunikasi Multimedia Malaysia.

Rogers, Y., Price, S., Harris, E., Phelps, T., Underwood, M., Wilde, D., \& Smith, H. (2002). Learning through digitallyaugmented physical experiences: Reflections on the ambient wood project. Equator Technical Report.

Sanchez, J., Salinas, A., \& Sáenz, M. (2006), Mobile game-based science learning. Retrieved June 18, 2007, from http://apru 2006.dir.u-tokyo.ac.jp/pdf/1a-4.pdf

Sanneblad, J., \& Holmquist, L. E. (2003). OpenTrek: A platform for developing interactive networked games on mobile devices. In Human-computer interaction with mobile devices and services (pp. 224-240). Heidelberg: Springer Berlin.

Savery, J. R., \& Duffy, T. M. (1995). Problem-based learning: An instructional model and its constructivist framework. Educational Technology, 35(5), 31-35. 
Schuman, L. (1996). Perspectives on instruction: Behaviourism, cognitivism, and constructivism. Retrieved August 20, 2009, from http://edweb. sdsu.edu/ courses/ edtec540/ Perspectives/ Perspectives.html

Siti Hafizah, A.H., \& Fung, L.Y. (2007, March ). Learn Programming by Using Mobile Edutainment Game Approach. Proceedings of the The First IEEE International Workshop on Digital Game and Intelligent Toy Enhanced Learning (DIGITEL '07), 170-172.

Sugar, S., \& Sugar, K. (2002). Primary games: Experiential learning activities for teaching children $K-8$. San Francisco: JosseyBass.

Syamsul Bahrin Zaibon, \& Norshuhada Shiratuddin. (2009). Towards developing mobile game-based learning engineering model. Proceedings of the World Congress on Computer Science and Information Engineering (CSIE), 7. IEEE Computer Society, (pp. 649-653).

Sloper, T., \& Burns, M. S. (2002). Sloperama's Game Biz Advice page. Retrieved August 20, 2009 from http://www.sloperama. com/advice/index.html on November 10, 2007.

Thornton, P., \& Houser, C. (2004). Using mobile phone in education. Proceedings of the 2nd International Workshop on Wireless and Mobile Technologies in Education. Taiwan.

Trifonova, A. (2003), Mobile Learning - Review of the Literature. Technical Report DIT-03-009, Informatica e Telecomunicazioni, University of Trento.

Vaishnavi, V. \& Kuechler, W. (2007). Design science research methods and patterns: Innovating information and communication technology. New York: Auerbach Publications.

Vassell, C., Amin, N., \& Patel, D. (2006). Mobile learning: Using SMS to enhance education provision. Proceedings of the 7th Annual Conference of the Higher Education Academy for Information and Computer Sciences. Dublin, Ireland.

Wagner, E. D. (2005). Enabling Mobile Learning. EDUCAUSE Review, 40(3), pp. 40-53.

Wood, D. F. (2003). ABC of Learning and Teaching in Medicine: Problem Based Learning, BMJ, 326.

Yuan, M. J. (2003). Develop state-of-the-art mobile games, JavaWorld.com. Retrieved March 10, 2007 from http://www. javaworld.com/javaworld/jw-11-2003/jw-1107-wireless. html?page $=1$ 